\title{
Undercover policing and the spectre of "domestic extremism": the covert surveillance of environmental activism in Britain
}

\author{
Raphael Schlembach, University of Brighton
}

\begin{abstract}
The spectre of environmental "domestic extremism" has long been postulated by police leaders and security analysts in Britain. It is a narrative that has justified the commitment of enormous amounts of government resources towards police intelligence work directed at non-violent direct action campaigns. Most controversially, this has included the long-term infiltration of environmental (and other) activist groups by undercover police. This article provides a critical analysis of the justifications put forward in support of the covert surveillance of environmental activists in Britain. The paper proceeds by way of a single case study a high profile, environmental direct action protest in the north of England - in order to reveal the levels of abuse, manipulation and deception at the basis of undercover protest policing. Through their court case, the activists involved with this action were able to obtain rare insights into the police authorisation documents for the undercover operation that had led to their arrests. An analysis of these documents provides us with a glimpse of the contradictory justifications given by senior police officers for infiltration - now under scrutiny by a public inquiry. The picture of undercover policing that has emerged in recent years gives ground for a re-assessment of the character and legitimacy accorded to the 'British model of protest policing', a re-assessment in which social movement scholarship should play a central part.
\end{abstract}

Keywords: undercover policing, covert surveillance, environmental activism, public inquiry, domestic extremism, public order

\section{Introduction}

Environmental direct action (EDA) is a recognisable aspect of protest politics in the United Kingdom. As a tactical repertoire, it has played a significant role in the opposition to road-building, genetically modified crops, the aviation and 'fossil fuel' industries amongst others (Wall, 1999; Seel et al., 2000;

Plows et al., 2004; Doherty et al., 2007; Russell et al., 2017). While in the most part expressly 
committed to non-violence, environmental activists have often experimented with innovative disruptive actions - from land occupations and squats to small-scale ‘ecotage’ and property damage. As in other societies with widespread support for strong environmental protection and ecological justice, the police in England and Wales have taken a keen interest. And although the existence of undercover operatives, either employed by the police or by private business, had long been assumed as a possibility, firm proof of the extent of this infiltration only came in October 2010 when a well-known and apparently committed activist, Mark Kennedy, was outed as a former undercover police officer.

Kennedy’s undercover deployment, which saw him build an elaborate cover identity using the alias Mark Stone, had lasted over seven years from his first appearance in the EDA scene in Nottingham in 2003, and it took him beyond England and Wales to infiltrate protest networks in Scotland, Ireland and several other European countries. Amongst the groups that he was active in during that time were the anti-G8 Dissent! network, the Camp for Climate Action, Saving Iceland and Rossport Solidarity. Whilst employed by the Metropolitan Police Service, and for a brief while by the private security company Global Open, Kennedy spent significant amounts of time living the life of his undercover persona. Issued with a fake identity and training to act as a covert human intelligence source (CHIS) for his home unit, the National Public Order Intelligence Unit (NPOIU), he deceived several women into long-term intimate relationships with him. Those relationships, and the friendships he struck up with other environmental activists, gave his fake identity a level of credibility and privileged access to the networks of activists, their communications and plans. The long-term deployment also caused profound emotional harm and suffering. After his exposure, the shock, disbelief and hurt experienced by those who were targeted by Kennedy and his supervisors in the NPOIU soon gave rise to a desire to understand why and how they had become targets for the sophisticated and lengthy undercover operations. Although their questions have been met with a wall of silence on the part of the police, answers are beginning to appear elsewhere.

Two Metropolitan Police undercover units have come under closer scrutiny in recent years: the 
Special Demonstration Squad (SDS) which used various names between 1968 and 2008 as part of the Metropolitan Police’s Special Branch and Kennedy’s NPOIU overseen by the Association of Chief Police Officers (ACPO) between 1999 and 2011. The full extent to which these units infiltrated protest groups including environmental campaigns remains unclear, but statements made by the Chief Constable of Derbyshire Police Mick Creedon, who headed the police-internal investigation Operation Herne, indicated that the SDS alone had targeted hundreds of groups and that some 150 undercover officers worked for both units (see Undercover Research Group, 2016 and Campaign Opposing Police Surveillance, 2016). The tactics used to develop and maintain cover identities are widely regarded as immoral and frequently unlawful, and are subject to ongoing criminal investigations and to an independent public inquiry into undercover practices and regulations in England and Wales. Policing protest through infiltration has involved the use of intimate and sexual relationships, often over a period of years, the use of dead children's identities as aliases without the knowledge of the deceased's parents, and withholding evidence from courts and juries. In some instances, police officers fathered children with the activists they had targeted (see Schlembach, 2016; Loadenthal, 2014; Lubbers, 2015).

Despite the enormous impact that this exposure had on activists and on their activism, social movement scholarship has not yet carried out an in-depth analysis. While in the past, the surveillance and infiltration of protest has often been neglected theoretically because of the obvious limitations placed on its empirical analysis, the public exposure of Kennedy and several of his former colleagues now warrants a thorough re-assessment of what we know about protester-police interactions, surveillance and repression in Britain over the past 50 years. The picture that emerges from those campaigners who are bringing to light the sustained involvement of undercover officers in key roles of social movement organisations and in informal activist groups is that monitoring, disruption and facilitation was integral to the policing strategy over this period. The analysis presented here is based on a reading of a specific protest event - the Drax 'coal train hijacking' in June 2008. Following the arrests of 29 activists, their trial and sentencing, it emerged that a key role in the protest had been 
played by Mark Kennedy. This information had been withheld from the defence lawyers. In the appeals process that followed, the activists were able to see the police's authorisation of the Kennedy deployment. The police narratives of ‘controlling domestic extremism' that serve as justifications for the infiltration of climate activists entailed in these documents are subjected to critical analysis and contrasted to interview data with some of the activists themselves.

My contention here is that the exposure of undercover police officers in activist communities pose a challenge to social movement scholarship in the sense that some of the most high-profile campaigns and protests in Britain since 1968 may have been shaped by the involvement of police infiltrators, and that public order policing was significantly informed by such deployments. The usual focus of social movement studies in Britain on the campaigners themselves - that is their background, politics, mobilisation repertoires, etc. - is insufficient here. Similarly, the study of overt policeprotester interactions, while important, needs to take account of the possibility that at an invisible level, policing decisions were made with more information and knowledge than previously assumed. Finally, we need to look at the possibility that the undercover police's role often went beyond intelligence gathering and involved both disruption and facilitation, with little or no accountability. It is proposed that existing social movement scholarship can be usefully brought into dialogue with surveillance studies and critical policing scholarship to meet this challenge.

\section{Intrusive police surveillance in Britain}

In the Marxist and critical criminological literature, the surveillance of militant and subversive political movements have long been seen as defining aspects of the state function, also in liberal democracies (e.g. Bunyan, 1977; Marx, 1988; Neocleous, 2008; Gillham, 2011). The early manifestations of the surveillance state in Britain warranted a different look at the key policing agencies tasked with fabricating and maintaining the hegemonic social and economic order in Britain amidst political conflict and industrial dispute. Maureen Cain, specifically, criticised the traditional focus by policing 
scholars on the visible forms of social control and policing, which failed to examine the invisible work of state agencies tasked with law and order:

\footnotetext{
They have ignored them theoretically because they were constrained to ignore them empirically. Thus 'the police' have been presented as a more or less homogenous structure, divided internally only by dominant preoccupation with traffic, juveniles, criminal investigation or just plain patrolling. That would not matter if one could simply adds [sic] on other functions - internal intelligence gathering, control of overseas spy operations, counter revolutionary preparations and so on - but one cannot. For to add on these extra tasks transforms the equation (Cain, cited in McLaughlin, 2007: 61).
}

Of course, in the neoliberal conjuncture, the police are rarely presented as a 'homogenous structure' since the plural policing paradigm has become prevalent. Yet, key work in this area is still unable to be applied directly to the post-9/11 and post-7/7 context of security policing or the gathering of intelligence for the purposes of informing policing strategies that deal with animal rights and environmental protest.

This notwithstanding, there is now a growing literature on the controversial undercover policing techniques used in Britain to gather intelligence on political activists and protest movements especially anti-racist and family justice campaigns, trade unionists, animal rights activists and environmental groups - including in some instances their long-term 'sexual infiltration' (Lewis and Evans, 2013; Loadenthal, 2014; Lubbers, 2015). Apart from such activist, journalistic and criminological accounts, parts of the academic debate on the subject has been carried out within the framework of (critical) terrorism studies (Spalek and O’Rawe, 2014; Bonino and Kaoullas, 2015) and draws on the narrative frameworks provided by former undercover police officers themselves (for example Lambert 2014; Mills 2013).

This debate centres on the role of the SDS and the NPOIU, two British covert policing units attached to the Metropolitan Police Service between 1968 and 2011, which are now subject to a public inquiry (Schlembach, 2016). It is the result of the exposures of (former) undercover officers such as 
Mark Kennedy and, crucially, details provided by a whistleblower, Peter Francis, who had worked for the Special Demonstration Squad. Francis alleged that the family of Stephen Lawrence had been kept under covert surveillance by his unit.

In what follows, I argue that protest research can usefully engage with critical policing scholarship and the surveillance studies field. In the field of social movement studies, the relative lack of research into undercover policing and infiltration may be explained by a fear to tap into conspiratorial language and an inability to verify accounts of infiltration that are supported by movement participants themselves. But the British case, a range of police-internal reports and the public inquiry allow social movement scholars to re-assess past and present protest by incorporating knowledge from policing studies, critical criminology and surveillance research. Examining the case of Mark Kennedy appears particularly productive due to the amount of information already unearthed by investigative journalists and targeted activists, as well as Kennedy’s corroboration of many of the accusations. Although the analysis presented in this article is focused on just one protest event that Kennedy was deployed to monitor, it is possible to reach more far reaching conclusions about the extent of surveillance of environmental activism, the justifications offered for it by the police surveillance units themselves, and the long-lasting impact on transgressive political protest.

\section{Environmental direct action and the criminal justice system}

The deployment of undercover officers to report on the political campaigns of left-wing and environmental activists in Britain does not just raise ethical questions of police practice and professionalism. It would be too easy to dismiss the transgressions that have so far been uncovered as 'rogue behaviour'. Instead, questions of a more straightforwardly political nature must be asked: to what extent is disruptive protest seen as a threat to national security and public safety?

In Britain, EDA is usually understood by social movement researchers through the lens of an anarchist and do-it-yourself ethos that is marked by suspicion towards state structures and corporate 
bodies. While action repertoires range from 'ecotage' to street carnivals, covert direct actions, taken together by large groups of activists who weigh the repercussions of being arrested for relatively minor offences are commonly seen as justified. The arrests of 29 activists who scaled a train carrying coal to Drax power station after bringing it to a controlled halt in 2008 is one such example, which can illustrate that facing arrest and prosecution are 'normal events in the life cycle of many protest movements’ (Barkan, 2006: 183). It also reveals how activists are acutely aware of the social and ideological construction of political dissent as violence, extremism or terrorism - and that they take measures to demarcate themselves from such labelling, even if authorities do not.

Importantly, in the UK at least, the demarcation of EDA from extremism and terrorism finds recognition in the criminal courts, specifically for indictable offences tried by juries. Comparing the civil law traditions of France and Belgium with the common law jurisdictions in England and Wales, Doherty and Hayes (2015) note the differential effects of juries on the criminal trials of environmental activists. Activists charged with criminal offences related to EDA, including the frequent charges of aggravated trespass, criminal damage or public order offences, have a significant chance of acquittal if they have the opportunity to argue their defence before a jury. Even where they are found guilty, they mostly incur minor sentences, such as conditional discharges, fines or community service. As examples, the trials of English activists who destroyed fields of genetically modified crops mostly ended in acquittals in Crown Courts (Doherty and Hayes, 2012; 2014). Acquittals by juries frequently followed 'lawful excuse' defences, with protesters pleading not guilty to charges brought under the Criminal Damage Act 1971. In recent years, English Crown Courts have acquitted activists charged with causing damage to genetically modified crops, factory equipment of weapons manufacturer EDO in Brighton and a US fighter plane at Fairford airbase (Doherty and Hayes, 2015: 36).

The overt surveillance of protest is now a routine aspect of public demonstrations in most Western democracies. It is often manifested in video surveillance (Ullrich and Wollinger, 2011) by police units specialised in intelligence gathering techniques. In Britain, this role is usually taken up by 
Evidence Gatherers (EG) and Forward Intelligence Teams (FIT) (Aston, 2017). It is worth noting however that the routine videoing of protest by state and private security actors is frequently met by new forms of video activism and counter-surveillance (Monahan, 2006; Bennett, 2008; Wilson and Serisier, 2010; Bradshaw, 2013; Daphi et al., 2013; Brisman, 2014). In contrast, technological surveillance of protest and intelligence-gathering through informants and infiltrators aim at invisibility. The involvement of undercover officers in direct action networks also raises important concerns regarding their relationship to the courts. According to Mark Ellison QC, who led an investigation into possible miscarriages of justice resulting from unsafe convictions, the involvement of undercover police was frequently withheld from the criminal trials of campaigners (Ellison and Morgan, 2015), a practice then Home Secretary Theresa May termed ‘appalling’ (Evans, 2015). As a result the convictions of campaigners were quashed because prosecutors withheld evidence, including the identity of undercover officers, from judges and juries.

\section{Case Study: Operation Pegasus and the Drax 29}

The quashed convictions of the activists who stood trial in the Drax 29 case also underpin my case study. In June 2008, a group of environmental protesters reportedly 'hijacked' a scheduled delivery of 1,000 tons of coal to Drax power station in Yorkshire, after they acted out the emergency procedures for stopping a train using red flag signals (BBC, 2008). Wearing white paper boiler-suits and one donning a costume of a canary bird, they were able to use the safety procedures to bring the train to a controlled halt. Twenty-nine activists were arrested and charged with stopping the train and obstructing the railway under the Malicious Damage Act 1861. Some of the Drax 29, as the group became known, defended themselves in Leeds Crown Court and were complimented by the judge for making an 'eloquent, sincere, moving and engaging’ case to the court (Wainwright, 2009). Nonetheless, they found themselves convicted of obstructing engines on railways. They all received non-custodial sentences, ranging from 60 hours community service to 12 months probation. Notably, the defendants 
were barred from making a 'lawful excuse' defence, as the prosecution did not base its case on the Criminal Damage Act 1971 Instead, they resorted to a ‘necessity’ defence, arguing that their actions were a necessary response to the threat of climate change. This echoed a successful lawful excuse defence by six Greenpeace activists who had been charged with criminal damage caused to the Kingsnorth coal-fired power station in South East England two years earlier (for a discussion see Doherty and Hayes, 2015).

Their acquittal by a jury was seen as a milestone for the climate action movement. In the Drax 29 case, on the other hand, the judge did not permit a 'climate change defence', effectively barring the defendants from calling expert witnesses.

In January 2014, the Court of Appeal quashed the Drax 29 sentences, ruling that there had been 'a complete and total failure, for reasons which remain unclear, to make a disclosure fundamental to the defence' (BBC, 2014). This failed disclosure refers to the deployment of Kennedy on the Drax protest as one of the drivers taking activists to the protest site. As a result of their wrongful convictions, several of the Drax defendants have been given 'core participant' status in the ongoing Undercover Policing Inquiry, where they will be asked to give evidence. As part of the appeals process, the activists were given access to the partially redacted police authorisation documents for Kennedy, which I have seen and to which I refer below. The 'Drax disclosure' gives us a rare insight into the details of an undercover operation targeting a group of non-violent protesters, as well as some indication of the justifications that senior police officers give for the deployment of CHIS. Issued by West Yorkshire Police, the document reviews 'the use and conduct' of its source. In the document, the identity of Kennedy is not disclosed. Instead, it makes reference to an undercover officer (UCO), to Kennedy's employer the National Public Order Intelligence Unit, and to what it has called 'Operation Pegasus'. It states that the review is issued to 'update the Authorising Officer on the progress of the operation to date' and to add two more individuals (with no obvious connection to the Drax protest) to 'the subjects authorised for specific infiltration by the UCO [Kennedy] and Operation Pegasus’. The disclosure 
concludes by affirming the presence of the undercover officer in the 'Climate Change campaign', citing his deployment as 'proportionate and necessary providing quality intelligence on groups planning serious criminal activity’.

\section{Dirty Data and Activist Narratives}

For the purpose of the following analysis, the Drax disclosure documents relating to Operation Pegasus are treated as 'hidden and dirty data' (Marx, 1984). This is defined by Marx (1984: 79) as 'information which is kept secret and whose revelation would be discrediting or costly in terms of various types of sanctioning'. Despite the relative absence of dirty data from social research, it has underpinned some innovative methodological approaches in surveillance studies (see Hameed and Monaghan, 2012; Walby and Monaghan, 2011). In and of themselves, the disclosures relating to this case are not particularly damaging. But detailed empirical material of this kind can inform our understanding of the larger picture. Taken together with information about undercover operations from subject access and freedom of information requests, whistle-blowers, civil cases, internal and independent reviews, as well as parliamentary scrutiny, the Drax disclosure helps us answer questions regarding the minutiae of undercover authorisations and justifications. It is also worth noting that the communications and justifications of undercover authorisations were intended to remain confidential and available to specific police sources only. In fact, senior police officers and managers have repeatedly pointed to the possible risks associated with confirming undercover operations.

To complement the analysis of the Drax disclosure and to consider a contrasting perspective, the analysis draws on four semi-structured interviews with Drax 29 protesters who had their convictions overturned on appeal. Two are now named core participants in the public inquiry. Although the defendants in the Drax 29 trial are publicly named, I have chosen to anonymise the respondents selected for this study. I have benefitted here from contacts made during extensive periods of fieldwork and participant observation between 2006 and 2011, including the Climate Camps at Drax, Heathrow, 
Kingsnorth, Blackheath Common and Edinburgh (see Schlembach, 2011, Schlembach et al., 2012). The small number of quotations that I use here to illustrate the activists' perspectives are from a separate study of how those protesters affected by long-term police intrusion engage with the official inquiry into undercover policing (see Schlembach, 2016) and for which ethical approval has been given.

\section{"Protest is not Terrorism"}

The exposure of undercover police so deeply embedded in social movements in Britain raises larger theoretical and operational issues. Here, however, I have decided to focus on a specific case study. Rehearsing the bigger picture (e.g. Bonino and Kaoullas, 2014) has unfortunately missed important points over how the moniker of 'domestic extremism' has been made to stick to a wide variety of activists and campaigners. It is clear from the narratives offered by activists themselves that the serious criminality angle promoted by the police agencies is severely limited. It is simply not in line with the kind of activities in which environmental protesters are engaged. It appears that the activists all experienced profound moments of dissociation or dissonance with the official or mediatised accounts of their actions.

In my interviews, dissonance was repeatedly expressed through searching questions and a sense of disbelief. Patrick, for example, asked:

In terms of protest in a democratic society how is the presence of the police within campaigns [...] justified? How prevalent were they? It's like we currently know about 15 of these cops, all of whom slept with the people they were spying on, all of whom took part in like really dubious and abusive practices. You know, there’s no cop that we know about that has a kind of nice, in inverted commas, clean record, even if you agree with the concept behind them infiltrating protest groups in the first place, which obviously we don’t!

Obviously there's all these different intertwining issues here and there's the underlying question of should these police have been on these kind of missions at all, infiltrating environmental groups, infiltrating peace or justice 
campaigns, infiltrating trade union workers, like just all this awful stuff they were doing?

Activists were also concerned that they were being tarnished with the terrorism brush, at a time when such labelling could be politically damaging. Joe stated:

Their [the police's] definition of terrorism is incredibly broad, it’s a really wide net that it casts. I think that you can see that in terms of the blurring of the line of what terrorism was and wasn't [in police accounts of protest].

So for instance in our case, part of the reason that I pushed to or made the move to get involved in this [the public inquiry into undercover policing] is because I know that they will, the police will, justify our infiltration on the grounds that our group was engaged in some sort of criminal activity or direct action or public disorder and violence, and they kind of described the group at one point as the most violent group in the land, which is a complete exaggeration.

For some, also the accusation of serious criminality did not mesh with the reality of protest activity. In fact, they questioned the relationship between the presence of undercover police in campaigns and law enforcement, as in most cases information gathered by covert sources did not lead to arrests or prosecutions. Toby said:

Years and years [of infiltration...], a lack of any visible impact of that involvement, they got away with it, and we became aware that from the moment of planning the action to the end, the police knew everything. They knew of some of the biggest and high profile direct actions, [...] not sure how that is consistent that we are an actual threat. My domestic extremism file [obtained via a subject access request from the Metropolitan police] only lists the demonstrations I was on. But I was still monitored.

While my interviewees tended to state that they posed no substantial risk to public order, Sean was more ambivalent:

I was shocked that the police could commit such abuses against animal and environmental campaigns. [But] you could argue that this [the suppression of dissent] is the function of the police and it is not that surprising that they want know what is going on. 
The ambivalence at the heart of such an assessment is also relevant to Operation Pegasus itself. At an operational level, undercover policing is justified as leading to intelligence for the purposes of preventing serious crime or prosecuting offenders. Yet for the majority of Kennedy's deployment, his intelligence was not used in this way. In fact, the intelligence picture that he contributed to building talked up the threat of domestic extremism - a purpose that my interviewees were clearly aware of when in one way or another, they all asserted the axiom that 'protest is not terrorism'.

\section{"Serious criminality and domestic extremism"}

The rationale for Kennedy's deployment on Operation Pegasus is provided in detail in the Drax disclosure documents, stating its goal to involve Kennedy in protest activity connected to the Camp for Climate Action. Climate Camp campaigners were treated as a compound group - targeted because of their political activity, not due to existing evidence of planned criminal actions. In one extract, the infiltration of activists is justified in this way:

It is very rare for collateral intrusion to occur because [Kennedy's name redacted] spends the majority of [his] time with likeminded people engaged in activism.

The minutiae of Kennedy’s deployment in relation to the Drax protest are revealed in his personal notebooks of the day of the protest:

I drove a van with a number of people in the back to a holding point for 0600 hours. A number of spotters were positioned along the train's route to call in when a coal train was spotted. I pulled up and people got out the back of the van. I saw them walk up the track. I saw people in bright orange uniforms with a red flag walk along the track towards the Aire River rail bridge.

Although Kennedy did not himself take part in halting the train, his role as a driver was clearly instrumental. That local authorising officers would seek to use covert surveillance for the monitoring of a non-violent, yet disruptive, direct action protest is not altogether surprising. 
But the Drax disclosure documents also entail a remarkable addition - a handwritten note by Anton Setchell, who at the time was the National Coordinator for Domestic Extremism (NCDE). Setchell was in charge of Kennedy's unit, the NPOIU, as well as two other anti-extremism units: the National Extremism Tactical Co-ordination Unit (NETCU) and the National Domestic Extremism Team. Notably, one of the UK's most senior counterterrorism police officers personally saw fit to recommend the deployment of Kennedy on the Drax protest. In his letter he writes:

My role is not that of authorising officer, but as NCDE, to have the opportunity to comment on this deployment prior to the AO [authorising officer] reviewing the authority... This operation/deployment is focused on key areas of Domestic Extremism which I can say sit in the 'priority area' of DE for England and Wales and without this asset in place, our intelligence picture would be significantly reduced and I would seek to replace this asset very quickly to regain our understanding of the intentions of the DE groups that are listed.

The covert surveillance of environmental direct action is regarded here as instrumental in intelligenceled policing of domestic extremism, especially with regards to environmental activism. This theme is echoed by Her Majesty’s Inspectorate of Constabulary (HMIC), which makes reference to the fight against ‘serious criminality and serious disruption’. In a 2012 review of the police infiltration of protest groups, HMIC states that climate activists posed a serious and violent threat to public safety. The NPOIU is described as providing

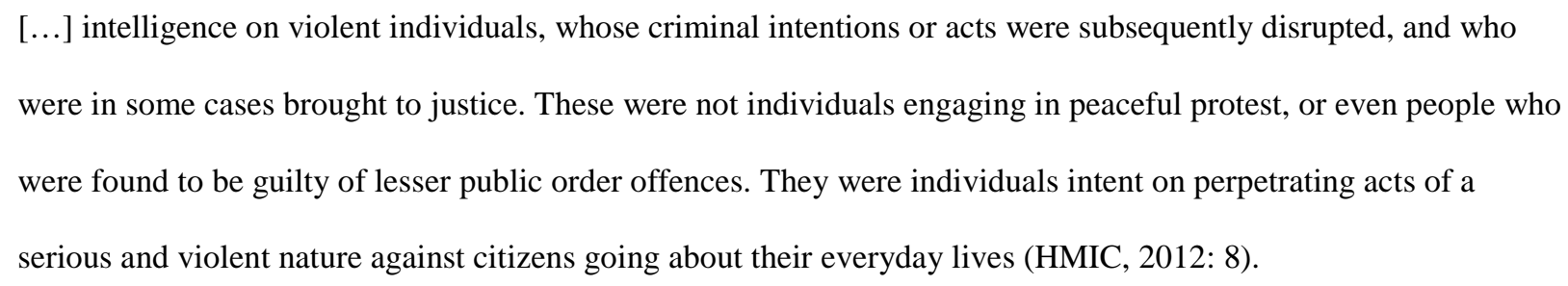

In the same report, environmental activism is offered as a specific example or violent and serious criminality: 
Environmental activists have been convicted of a range of offences over the last 10 years, associated with protests against (for instance) genetically modified crops; the burning of coal; and the expansion of aviation. Notable incidents have included the hijacking of a coal train in 2009 [sic], and conspiracies to disrupt power supplies (HMIC, 2012: 15).

The perceived 'threat' posed by environmental protest was also a stated purpose in the authorisation of Kennedy's involvement in the Drax coal train protest, which explicitly referred to the risk climate activists could pose to the public and permitted Kennedy to get involved in 'actions connected to Climate Camp where the threat to the public is greater'.

\section{Intelligence-led public order policing?}

The police, police inspectorate and others have justified the deployment of undercover officers in environmental groups by exaggerating the threat posed by EDA towards public safety and national security. Yet, violence rarely forms part of the police's delineation of domestic extremism, as in that given by the (now defunct) Association of Chief Police Officers (ACPO).

\footnotetext{
Domestic extremism and extremists are the terms used for activity, individuals or campaign groups that carry out criminal acts of direct action in furtherance of what is typically a single issue campaign. They usually seek to prevent something from happening or to change legislation or domestic policy, but attempt to do so outside of the normal democratic process (ACPO, cited in HMIC, 2012).
}

In descriptions such as these, environmental protesters are variously labelled 'domestic extremists' or 'serious criminals', although clear definitions are frequently missing. But recent studies of anti-fracking protest in England have further documented that non-permissive and repressive policing tactics are based on police terminology that continues to demarcate rather arbitrarily between 'good' and 'bad' protesters, whereby 'the boundaries between acceptable and unacceptable protest in the police 
definition are not based on the use of violence but on the target and the desire to be disruptive’ (Jackson, et al., 2018). This dissonance between 'extremism' and 'legitimate protest' could be analysed as a 'framing war' (Hilson, 2012: 48): Climate change protesters are depicted by police and prosecutors as domestic extremists or otherwise opposed to basic democratic freedoms; meanwhile, they and their supporters highlight their image as non-violent defenders of environmental protection and international climate agreements.

In the Drax 29 case, the dissonance between 'extremism’ and disruption was also apparent in the lenient sentencing and the judge's praise for the activists' health and safety considerations, quite in contrast to the police's framing of the group as a potential threat to public safety. It is further illustrated by the wider climate action movement in the UK, which is characterised by consistently non-violent protest even when faced with aggressive public order tactics (Greer and McLaughlin, 2010; Rosie and Gorringe, 2009; Baker, 2011; Gorringe and Rosie, 2013).

The organisational background to the Drax coal train occupation was the British Camp for Climate Action - or Climate Camp - which existed as a network of environmental activists who put much of their organisational efforts into staging annual protest camps leading to mass direct actions. In 2006, Climate Camp had chosen the Drax power station as a site for protest when it held a week-long action camp in a field a short distance from its imposing cooling towers, with some 700 activists in attendance, including Kennedy, who had taken a leading role in the logistical work to establish it as a base for an attempted (but failed) mass trespass of the power station site. In a police report, it is claimed that this was 'the first time domestic extremism took place against national infrastructure in the country’ (cited in Evans et al., 2009). Two years later, Climate Camp returned with an even larger camp not far from a coal-fired power station. This time, they pitched up on the Hoo peninsula in the south of England with Kingsnorth power station as its visible backdrop. Again, a widely-publicised mass trespass was prevented by a large policing operation with protesters staging a demonstration at 
the power station's front gate instead.

The policing of the Climate Camps makes for an interesting setting to the infiltration of the activist group that planned the Drax coal train occupation. The policing at Kingsnorth in particular has been described as ‘intimidation’ with ‘ 1400 police officers from over 26 forces, making the policeparticipant ratio almost 1:1’ (Saunders and Price, 2009: 118). Visitors to the camp were immediately struck by the overt police presence around the camp’s perimeter. A first 'check-point' was set up a couple of miles before one could get to the camp, with police pulling over cars and mini-buses taking protesters to the site and registering number plates and the personal details of the drivers. The campers were not permitted to drive down the public access road to the camp. Campaign equipment and food for the week-long protest camp had to be carried on foot for the last bit of the way. On arrival, police had set up a large stop-and-search area outside the entrance of the camp. Those entering and leaving would routinely be subjected to searches under Section 1 of the Police and Criminal Evidence Act or Section 60 of the Criminal Justice and Public Order Act, which meant that many participants were searched several times each day. Up the track past the stop-and-search area, new arrivals were greeted by a group of police with camera equipment taking film footage and photographs of everybody attending. The overt surveillance of the camp's entrance point became one of the sore points of the police operation, with some also noting 'persistent noisy surveillance from the air' (Saunders and Price, 2009: 118), the confiscation of essential camping items, and early morning raids of the site by large numbers of police in anti-riot equipment making sporadic use of batons and pepper spray.

Other than the police's own reviews into the policing of the Kingsnorth Climate Camp, there is little academic research. In one publication, Chief Inspector Adrian Moody, the principal team planner for the policing operation - Operation Oasis - argues that the police’s planning 'occurred within a vacuum, devoid of adequate intelligence, information and dialogue’ (cited in Baker, 2011: 147). The Chief Inspector's assertion appears implausible. Kennedy and possibly other undercover officers 
(UCOs) had taken active roles in the organisation of the successive Climate Camps as well as in the more secretive discussions in planning the trespass of the power station. The police certainly did not have to 'rely on “open” sources’ (Baker, 2011: 147), as Moody insinuated. It is possible, though unlikely, that Moody in his role as the 'principal Oasis team planner' was left in the dark over the presence of UCOs within the organisation of the camp. But as Kennedy’s authorisation documents indicate, the communication between UCOs and their handlers was almost constant, so information about 'who, where, when and what' was available to key police personnel within his unit and to the authorising officers.

As others have noted, 'the ability of the authorities to defend a target named in advance, and to control or repress a camp site in open countryside is strong' (North, 2011: 1593). But the ability to control and repress also rests heavily on the surveillance powers and capacities of which the police can make use. Whereas the disruptions to coal-fired power stations at the Climate Camps near Drax and near Kingsnorth had been called publicly and the organisation of the camps was semi-open, the more clandestine direct action of smaller groups of activists to disrupt the Drax power station by stopping a delivery of coal provided the police with a more formidable challenge. In such cases, intrusive surveillance has been a neglected ingredient in the police planning for public order management. In short, where the police agencies could not reasonably pre-empt its response to a protest event due to a lack of dialogue with organisers, they appear to have relied on covert intelligence sources to a greater extent than previously assumed. Further, the aim of protest infiltration, as in the preceding case study, was not the prevention of serious crime or of mitigating a threat to public safety. Rather what was at stake was the ability to regulate, facilitate and if needed incapacitate transgressive protest that evaded the traditional police-protester interactions and posed fundamental questions and challenges to key public policy fields. 


\section{Conclusion}

The disclosure of the surveillance authorisation and operational logs in the Drax 29 case - analysed here as hidden and dirty data - has given us a rare chance to study police narratives of undercover work, including its justifications at management-level. It has shown that also when intrusive surveillance is targeted at protest groups it remains 'embedded in the most mundane aspects of social life’ (Loftus and Goold, 2012: 285). The emotional and intimate relationships that UCO Kennedy had fostered with activists allowed him to remain deep undercover within EDA groups and to feed information about planned protest activities to his handlers. But as suggested, the covert policing of protest is not designed to detect and prevent crime; it is to fabricate and maintain order (Neocleous, 2000).

This study has also provided further evidence of the Janus-faced quality of contemporary protest policing (see Wilson and McCulloch, 2012). In the field of public order policing, on the one hand, efforts have been made at a high level to validate the notion of a British model of protest policing that relies on communication, negotiated management and protester-police liaison (for example HMIC, 2009). Such an approach is often encouraged by a research community that seeks the democratic accountability of the police's use of force and the guarantee of the human rights of protesters (for a critical engagement in the US context see McClanahan and Brisman, 2017). Invisible to the field of public order policing, on the other hand, lies a simultaneous development of covert policing tactics and technologies that drives advances in pre-emptive crime control, unaccountable and political policing, and post-democratic constructions of 'political threats' (McCulloch and Wilson, 2015). These are key elements of what Noakes and Gillham (2006) have called ‘strategic incapacitation'. The two trends are not necessarily contradictory. It remains true that 'a police policy of toleration in the face of public demonstrations can certainly coexist with a policy of covert dirty tricks’' (Marx, 1998: 264). 
Certainly, the surveillance of environmental protest and the discursive construction of transgressive protest as ‘extremism’ is not new. However, the recent exposures of police officers who operated undercover in social movements and protest groups in Britain add to our understanding of how surveillance works at a mundane level, and how it is justified by police decision-makers. The targeted activists are in no way 'surprised' that the police took an interest in their activities. But they remain shocked by the detail and the extent of infiltration.

\section{References}

Aston, V. (2017). State surveillance of protest and the rights to privacy and freedom of assembly: A comparison of judicial and protester perspectives. European Journal of Law and Technology, 8(1), 119.

Baker, D. (2011). A case study of policing responses to camps for climate action: Variations, perplexities, and challenges for policing. International Journal of Comparative and Applied Criminal Justice, 35(2), 141-165.

Barkan, S. (2006). Criminal prosecution and the legal control of protest. Mobilization, 11(2), 181-195. BBC (2008, June 13). Climate protest halts coal train. BBC News. Retrieved from http://news.bbc.co.uk/1/hi/england/north_yorkshire/7452395.stm.

BBC (2014, January 21). Drax protesters' undercover police case convictions quashed. BBC News. Retrieved from http://www.bbc.co.uk/news/uk-england-25829169.

Bennett, C. (2008). The privacy advocates: Resisting the spread of surveillance. Cambridge, MA: The MIT Press.

Bonino, S., \& Kaoullas L. G. (2014). Preventing political violence in Britain: An evaluation of over forty years of undercover policing of political groups involved in protest. Studies in Conflict \& Terrorism, 38(10), 814-840.

Bradshaw, E. (2013). This is what a police state looks like: Sousveillance, direct action and the anticorporate globalization movement. Critical Criminology, 21(4), 447-461.

Brisman, A. (2014). In the garden with "creative crime”: Kudzu and the third branch. In M. H. Jacobsen (Eds.) The poetics of crime: Understanding and researching crime and deviance through creative sources (pp. 51-70). Surrey, UK: Ashgate.

Bunyan, T. (1977). The history and practice of the political police in Britain. London: Quartet Books. Campaign Opposing Police Surveillance (2016, September 1). How many spycops have there been? Retrieved from http://campaignopposingpolicesurveillance.com/2016/09/01/how-many-spycops-havethere-been/.

Daphi, P., Lê, A., \& Ullrich, P. (2013). Images of surveillance: The contested and embedded visual language of anti-surveillance protests. In N. Doerr, A. Mattoni \& S. Teune (Eds.) Advances in the visual analysis of social movements (pp. 55-80). Bingley: Emerald.

Doherty, B. \& Hayes, G. (2012). Tactics, traditions and opportunities: British and French crop-trashing actions in comparative perspective. European Journal of Political Research, 51(4), 540562. 
Doherty, B. \& Hayes, G. (2014). Having your day in court: Judicial opportunity and tactical choice in anti-GMO campaigns in France and the United Kingdom. Comparative Political Studies, 47(1), 3-29. Doherty, B. \& Hayes, G. (2015). The courts: Criminal trials as strategic arenas. In J. W. Duyvendak \& J. M. Jasper (Eds.) Breaking down the state (pp. 27-52). Amsterdam: Amsterdam University Press. Doherty, B., Plows, A., \& Wall, D. (2007). Environmental direct action in Manchester, Oxford and North Wales: A protest event analysis. Environmental Politics, 16(5), 804-824.

Ellison, M., \& Morgan, A. (2015). Review of possible miscarriages of justice: Impact of undisclosed undercover police activity on the safety of convictions (Report to the Attorney General). London: Home Office.

Evans, R., \& Lewis, P. (2013). Undercover: the true story of Britain's secret police. London: Faber and Faber Ltd.

Evans, R., Lewis, P., \& Taylor, M. (2009, October 25). How police rebranded lawful protest as 'domestic extremism'. The Guardian. Retrieved from

https://www.theguardian.com/uk/2009/oct/25/police-surveillance-protest-domestic-extremism.

Gillham, P. F. (2011). Securitizing America: Strategic incapacitation and the policing of protest since the 11 September 2001 terrorist attacks. Sociology Compass, 5(7), 636-652.

Gorringe, H., \& Rosie, M. (2013). 'We will facilitate your protest': Experiments with liaison policing. Policing, 7(2), 204-211.

Greer, C., \& McLaughlin, E. (2010). We predict a riot? Public order policing, new media environments and the rise of the citizen journalist. British Journal of Criminology, 50(6), 1041-59.

Hameed, Y., \& Monaghan, J. (2012). Accessing dirty data: Methodological strategies for social problems researchers. In M. Larsen \& K. Walby (Eds.) Brokering access: Politics, power and freedom of information in Canada (pp. 142-168). Vancouver: UBC Press.

Hilson, C. (2012). UK climate change litigation: Between hard and soft framing. In S. Farrall, T. Ahmed, \& D. French (Eds.) Criminological and legal consequences of climate change: Oñati international series in law and society (pp. 47-61). Oxford: Hart Publishing. HMIC (2009). Adapting to protest (Report). London: Her Majesty’s Inspectorate of Constabulary. HMIC (2012). A review of national police units which provide intelligence on criminality associated with protest (Report). London: Her Majesty’s Inspectorate of Constabulary.

Jackson, W., Gilmore, J. \& Monk, H. (2018). Policing unacceptable protest in England and Wales: A case study of the policing of anti-fracking protests. Critical Social Policy, 1-21, DOI:

10.1177/0261018317753087, 1-21.

Lambert, R. (2014). Researching counter-terrorism: A personal perspective from a former undercover police officer. Critical Studies on Terrorism, 7(1), 165-181.

Loadenthal, M. (2014). When cops 'go native': Policing revolution through sexual infiltration and panopticonism. Critical Studies on Terrorism, 7(1), 24-42.

Loftus, B., \& Goold, B. (2012). Covert surveillance and the invisibilities of policing. Criminology and Criminal Justice, 12, 275-288.

Lubbers, E. (2015). Undercover research: Corporate and police spying on activists. An introduction to activist intelligence as a new field of study. Surveillance \& Society, 13(3/4), 338-353.

Marx, G. (1988). Undercover: police surveillance in America. Berkeley: University of California Press. McCulloch, J., \& Wilson, D. (2015). Pre-crime: Pre-emption, precaution and the future. Abingdon and New York: Routledge.

Marx, G. (1998). Afterword: Some reflections on the democratic policing of demonstrations. In D. Della Porta \& H. Reiter (Eds.) Policing protest: The control of mass demonstrations in Western democracies (pp. 253-269). Minneapolis: University of Minnesota Press.

McClanahan, B., \& Brisman, A. (2017). Police violence and the failed promise of human rights. In L. Weber, E. Fishwick \& M. Marmo (Eds.) The Routledge Handbook of Criminology and Human Rights (pp. 333-341). London and New York: Routledge. 
McLaughlin, E. (2007). The New Policing. London: Sage.

Monahan, T. (2006). Counter-surveillance as political intervention? Social Semiotics, 16(4), 515-534.

Neocleous, M. (2000). The fabrication of social order: A critical theory of police power. London: Pluto Press.

Neocleous, M. (2008). Critique of security. Edinburgh: Edinburgh University Press.

Noakes, J., \& Gillham, P. F. (2006) Aspects of the 'New Penology' in the police response to major political protest in the United States, 1999-2000. In D. Della Porta, A. Peterson \& H. Reiter (Eds.) The policing of transnational protest (pp. 97-115). Abingdon: Ashgate.

North, P. (2011). The politics of climate activism in the UK: A social movement analysis. Environment and Planning A, 43(7), 1581-1598.

Plows, A., Wall, D., \& Doherty, B. (2004). Covert repertoires: Ecotage in the UK. Social Movement Studies, 3(2), 199-219.

Rosie, M. \& Gorringe, H. (2009). What a difference a death makes: Protest, policing and the press at the G20. Sociological Research Online, 14(5), http://www.socresonline.org.uk/14/5/4.html.

Russell, B., Schlembach, R., \& Lear, B. (2017). Carry on camping? The British Camp for Climate Action as a political refrain. In G. Brown, A. Feigenbaum, F. Frenzel \& P. McCurdy (Eds.) Protest camps in international context: Spaces, infrastructures and media of resistance (pp. 147-162). Policy Press: Bristol.

Saunders, C., \& Price, S. (2009). One person's eu-topia, another's hell: Climate Camp as a heterotopia. Environmental Politics, 18(1), 117-122.

Schlembach, R., (2011). How do radical climate movements negotiate their environmental and their social agendas? A study of debates within the Camp for Climate Action (UK). Critical Social Policy, 31(2), 194-215.

Schlembach, R., (2016). The Pitchford inquiry into undercover policing: Some lessons from the preliminary hearings. Papers from the British Criminology Conference, Vol. 16,

http://www.britsoccrim.org/wp-content/uploads/2016/12/pbcc_2016_Schlembach.pdf.

Schlembach, R., Bowman, A. \& Lear, B. (2012). Science and ethics in the post-political era: Strategies within the Camp for Climate Action. Environmental Politics, 21(5), 811-828.

Seel, B., Paterson, M., \& Doherty, B. (Eds.) (2000). Direct action in British environmentalism. London: Routledge.

Spalek, B., \& O’Rawe, M. (2014). Researching counter-terrorism: A critical perspective from the field in light of allegations and findings of covert activities by undercover police officers. Critical Studies on Terrorism, 7(1), 150-164.

Ullrich, P., \& Wollinger, G. R. (2011). A surveillance studies perspective on protest policing: The case of video surveillance of demonstrations in Germany. Interface: a journal for and about social movements, 3(1), 12-38.

Undercover Research Group (2016, June 22). 460 groups spied upon...? Retrieved from http://undercoverresearch.net/2016/06/21/460-groups-spied-upon/.

Wainwright, M. (2009, July 2). Jury retires to consider verdict in Drax hijack trial. The Guardian. Retrieved from https://www.theguardian.com/environment/2009/jul/02/drax-protester-trial-jury-retires. Walby, K., \& Monaghan, J. (2011). Private eyes and public order: Policing and surveillance in the suppression of animal rights activists in Canada. Social Movement Studies, 10(1), 21-37.

Wall, D. (1999). Earth First and the anti-roads movement. London: Routledge.

Wilson, D., \& McCulloch, J. (2012). (Un)controlled operations: Undercover in the security control society. In J. McCulloch \& J. Pickering (Eds.) Borders and crime: Pre-crime, mobility and serious harm in an age of globalization. (pp. 163-178). Basingstoke: Palgrave Macmillan.

Wilson, D., \& Serisier, T. (2010). Video activism and the ambiguities of counter-surveillance. Surveillance \& Society, 8(2), 166-180. 